\title{
Calcium balance studies on children accustomed to low calcium intakes
}

\author{
By ALMAS BEGUM AND SHEILA M. PEREIRA \\ Nutrition Research Unit, Christian Medical College and Hospital \\ Vellore, Tamil Nadu, India \\ (Received I4 April I969-Accepted I fuly 1969)
}

\begin{abstract}
I. Calcium balance studies were carried out on twenty-eight apparently normal preschool children who had been for several months on a low Ca intake of $200 \mathrm{mg} / \mathrm{child}$ per day.

2. Three-day balances showed that all subjects were in positive balance. The absorption was $50 \%$ of the intake.

3. When the dietary intake was increased to $280 \mathrm{mg} /$ day there was a greater absorption and retention of $\mathrm{Ca}$. Serum $\mathrm{Ca}$, inorganic phosphorus and alkaline phosphatase were within the normal range for this age group.

4. Fourteen of the subjects were on wheat supplemented with lysine. The addition a single amino acid to the diet was shown not to improve the absorption and retention of $\mathrm{Ca}$ over that of the controls.
\end{abstract}

Hegsted (1959) defined the minimal requirement as the smallest amount of a nutrient which will support normal performance or prevent detectable signs of nutrient deficiency. However, the dietary intakes of calcium recommended by expert groups cater for the great variability in individual requirements. The recommended allowance for adults suggested by the National Research Council: Food and Nutrition Board ( 1968 ) is $80 \mathrm{mg} /$ day; the Indian Council of Medical Research (1966) suggests rooo mg/ day. A joint FAO/WHO Expert Group (WHO, I962) decided that, owing to the limited information available and the adaptation of individuals to low intakes, a specific value for the minimum requirement for $\mathrm{Ca}$ could not be clearly defined. They suggested a daily intake of $400-500 \mathrm{mg}$ for adults and an intake of $400-500 \mathrm{mg}$ a day for children of preschool age.

In diet surveys conducted in Tamil Nadu, India, the measured intakes of $\mathrm{Ca}$ of preschool children were found to be around $200 \mathrm{mg}$ a day (Sundararaj, Begum, Jesudian \& Pereira, I $969 a, b)$.

The present studies were undertaken to determine the efficiency of $\mathrm{Ca}$ absorption by preschool children accustomed to similar low $\mathrm{Ca}$ intakes.

\section{MATERIAL AND METHODS}

Subjects. Twenty-eight children aged from 3 to 5 years took part in the study. All the children were residents in an orphanage and were in apparent good health.

Diet. The diet contained wheat, pulses and vegetables (potatoes, raw bananas, brinjals, ladies fingers, etc.) commonly eaten by the local population. The food was served as four meals a day. The wheat given to half the subjects was supplemented 
with DL-lysine hydrochloride at the $0.25 \%$ level; the other children were given unsupplemented wheat. The children on supplemented wheat consumed $0.25 \mathrm{~g}$ lysine/ $100 \mathrm{~g}$ wheat in addition to the lysine content of the wheat. Each child's portion was weighed at every meal and the children were encouraged to finish their portions. Uneaten food, if any, was weighed and accounted for in the calculations. A record was kept of the water drunk by a representative sample of children.

All subjects were on the diet for a minimum period of 4 months before the start of the study.

Biochemical methods. Ca balance studies were carried out on each child for a 3-day period. Food, urine and faeces were collected every $24 \mathrm{~h}$ and samples were analysed separately.

On each of the 3 days a quantity of food identical to that consumed by each child was homogenized, and the Ca content was estimated by permanganate titration of the ashed food.

Urine and faeces were collected and preserved by the methods described by Murthy, Swaminathan \& Subrahmanyan (1954). Stools were homogenized in a Waring Blendor and portions were weighed out and ashed. The ash was dissolved in $2 \mathrm{~N}$-hydrochloric acid. The $\mathrm{Ca}$ content of the extract was determined by McCrudden's (1912) permanganate titration method. Urinary $\mathrm{Ca}$ was determined by Hooper's (1956) micromethod.

Serum Ca was determined by the method of Clark \& Collip (1925), serum alkaline phosphatase activity by the method of King \& Jagadesan (1959), and Fiske \& Subbarow's (1925) method was used for measuring inorganic phosphorus.

\section{RESULTS}

The mean age of the children was $4 \cdot 5\left(2 \cdot 75^{-5} \cdot 5\right)$ years, their mean weight was $13^{\cdot} 6$ $(10 \cdot 0-16.6) \mathrm{kg}$ and their mean height was $98(88-109) \mathrm{cm}$. The heights and weights of the subjects were similar to those of average south Indian children (Indian Council of Medical Research, 1958).

The components and nutritive value of the diet eaten by the children are given in Table $\mathrm{r}$. The daily diet provided, on an average, $2 \mathrm{~g}$ protein and $90 \mathrm{kcal} / \mathrm{kg}$ bodyweight. The average daily intake of $\mathrm{Ca}$, inclusive of that from drinking water, was $204^{\circ} \mathrm{mg}$. The phosphorus content of the diet was high, the ratio of $\mathrm{Ca}$ to $\mathrm{P}$ being I:3. The intake of vitamin $A$ as carotene was low but similar to the carotene intake of preschool children in this area (Sundararaj et al. $1969 a, b$ ). The institution diet provided more fat, as groundnut oil, than is usually consumed by south Indian preschool children.

The results of $\mathrm{Ca}$ balance studies are presented in Table 2. The mean dietary $\mathrm{Ca}$ intake was 204. $\mathrm{mg}$ per child per day. All the children were in positive Ca balance on this intake, the average absorption being $103 \mathrm{mg}$. The faecal excretion was 101 $4 \mathrm{mg}$. On an average, $26.2 \mathrm{mg} \mathrm{Ca}$ was lost in the urine. The mean retention was $76.9 \mathrm{mg}$, or $38.5 \%$ of intake.

Though there was a wide range in the retention of $\mathrm{Ca}$, thirteen of the twenty-eight 
children retained more than $40 \%$ of the dietary intake. In eleven children the retention was above $30 \%$ of the dietary intake. Only one child retained less than $20 \%$.

Serum $\mathrm{Ca}, \mathrm{P}$ and alkaline phosphatase were determined in twenty-five children and the results are summarized in Table 3 . The mean serum concentration of $\mathrm{Ca}$ was $10.3 \pm 0.3 \mathrm{Img} / \mathrm{r} 00 \mathrm{ml}$, of inorganic $\mathrm{P} 6.3 \pm 0.37 \mathrm{mg} / \mathrm{I} 00 \mathrm{ml}$, and of alkaline phosphatase 16.4 King Armstrong units/100 $\mathrm{ml}$. All values were within the normal range except that for inorganic $P$ which was slightly higher than the values reported for children by Varley ( 1963 ) and probably reflects the rapid bone formation at this age.

\begin{tabular}{|c|c|c|c|}
\hline \multicolumn{2}{|l|}{ Components (g/child day) } & \multicolumn{2}{|c|}{ Nutrient content (per child per day) } \\
\hline Wheat & $\mathrm{x} 89^{\circ} 0$ & Energy (kcal) & Ir 80 \\
\hline Black gram & $8 \cdot 0$ & Protein $(g)$ & $26 \cdot 3$ \\
\hline Oil & $39 \cdot 2$ & Fat $(\mathrm{g})$ & $42 \cdot 4$ \\
\hline \multirow{3}{*}{$\begin{array}{l}\text { Vegetables (potato, brinjal, } \\
\text { raw banana, etc.) }\end{array}$} & 55.0 & Carbohydrate (g) & 172 \\
\hline & & Calcium (mg) & 196 \\
\hline & & Phosphorus (mg) & 675 \\
\hline Jaggery & $19 \cdot 0$ & Vitamin A (i.u.) & 318 \\
\hline Onions & $3 \mathrm{r} \cdot 0$ & - & \\
\hline Chillies & 2.8 & - & 一 \\
\hline Condiments & $4 \cdot I$ & - & - \\
\hline
\end{tabular}

* Calculated from values given by Indian Council of Medical Research (I966).

Table 2. Daily intake, retention and absorption of calcium in twenty-eight children accustomed to low intakes of calcium, before and after the addition of green vegetables to their diet (Mean values and standard deviations)

\begin{tabular}{|c|c|c|c|c|c|c|}
\hline Diet & $\begin{array}{l}\text { Intake } \\
\text { (mg) }\end{array}$ & $\begin{array}{l}\text { Urine } \\
\text { (mg) }\end{array}$ & $\begin{array}{c}\text { Faeces } \\
(\mathrm{mg})\end{array}$ & $\begin{array}{l}\text { Absorption } \\
\text { (mg) }\end{array}$ & $\begin{array}{l}\text { Retention as } \\
\% \text { of intake }\end{array}$ & $\begin{array}{l}\text { Absorption as } \\
\% \text { of intake }\end{array}$ \\
\hline $\begin{array}{l}\text { Is in Table } \mathrm{I} \\
\text { Is in Table } \mathrm{I}+ \\
\text { green vegetables }\end{array}$ & $\begin{array}{l}204^{\circ} 0 \pm 8 \cdot 6 \\
28 I \cdot 0 \pm 3 I \cdot I\end{array}$ & $\begin{array}{l}26 \cdot 2 \pm 9 \cdot 2 \\
34 \cdot 3 \pm 21 \cdot 8\end{array}$ & $\begin{array}{l}\text { I0I. } 4 \pm 19 \cdot 7 \\
\text { 105.5 } \pm 48 \cdot 1\end{array}$ & $\begin{array}{l}103 \cdot 0 \pm 21 \cdot 0 \\
176 \cdot 2 \pm 44 \cdot 1\end{array}$ & $\begin{array}{l}38 \cdot 5 \pm 10 \cdot 3 \\
54 \cdot 0 \pm 16 \cdot 0\end{array}$ & $\begin{array}{l}50 \cdot 3 \pm 9 \cdot 7 \\
62 \cdot 7 \pm 16 \cdot 1\end{array}$ \\
\hline
\end{tabular}

Table 3. Serum calcium, inorganic phosphorus and alkaline phosphatase measured in twenty-five children on low intakes of vitamin $A$, and changes in alkaline phosphatase following an oral dose of 10000 i.u. vitamin $A$

(Mean values and standard deviations; values in parentheses are ranges)

\begin{tabular}{|c|c|c|c|}
\hline \multirow[b]{2}{*}{$\begin{array}{c}\text { Calcium } \\
(\mathrm{mg} / 100 \mathrm{ml})\end{array}$} & \multirow[b]{2}{*}{$\begin{array}{l}\text { Inorganic phosphorus } \\
(\mathrm{mg} / 100 \mathrm{ml})\end{array}$} & \multicolumn{2}{|c|}{ Alkaline phosphatase (K.A.)* } \\
\hline & & Before vitamin A & After vitamin A \\
\hline $\begin{array}{l}10.3 \pm 0.31 \\
(9 \cdot 6-11 \cdot 2)\end{array}$ & $\begin{array}{l}6 \cdot 3 \pm 0 \cdot 37 \\
(5 \cdot 7-6 \cdot 8)\end{array}$ & $\begin{array}{l}16.4 \pm 0.89 \\
(1 \times \cdot 0-26 \cdot 3)\end{array}$ & $\begin{array}{l}5 \cdot 0 \pm 0.42 \\
(4 \cdot 1-7 \cdot 17)\end{array}$ \\
\hline
\end{tabular}

Of the twenty-eight children, half were fed on wheat supplemented with lysine. The $\mathrm{Ca}$ balances of ten children from each group are presented in Table 4 . The children on lysine-supplemented wheat absorbed $60.9 \%$ of dietary $\mathrm{Ca}$ compared with $60.3 \%$ of the unsupplemented group. The variability in the retention and 
absorption might have been due to a smaller number of children studied. The differences in absorption and retention were not statistically significant.

When the children were on a diet providing $300 \mathrm{i} . \mathrm{u}$. vitamin A as carotene, the mean serum alkaline phosphatase was $\mathrm{I} 6.4$ units/100 $\mathrm{ml}$. By $24 \mathrm{~h}$, after an oral dose of 10000 i.u. vitamin $A$, the mean value had dropped to 5.0 units $/ 100 \mathrm{ml}$. The effect of vitamin $A$ on the serum alkaline phosphatase is shown in Table 3.

Table 4. Calcium balances of ten children given lysine-supplemented wheat compared with those of ten children given unsupplemented wheat

\begin{tabular}{|c|c|c|c|c|c|}
\hline Diet & $\begin{array}{l}\text { Intake } \\
(\mathrm{mg})\end{array}$ & $\begin{array}{l}\text { Urine } \\
\text { (mg) }\end{array}$ & $\begin{array}{l}\text { Faeces } \\
\text { (mg) }\end{array}$ & $\begin{array}{l}\text { Retention as } \\
\% \text { of intake* }\end{array}$ & $\begin{array}{l}\text { Absorption as } \\
\% \text { of intake* }\end{array}$ \\
\hline $\begin{array}{l}\text { Lysine-supplemented } \\
\text { wheat }\end{array}$ & $278 \cdot 8 \pm 32$ & $29^{\circ} 9$ & 115.9 & $49^{\cdot 2} \pm \mathrm{I} 8 \cdot 5$ & $60.9 \pm 16.8$ \\
\hline Unsupplemented wheat & $282 \cdot 7 \pm 32$ & $38 \cdot 4$ & $110 \cdot 12$ & $46 \cdot 4 \pm 18 \cdot 9$ & $60 \cdot 3 \pm 14 \cdot 5$ \\
\hline
\end{tabular}

Table 5. Serum alkaline phosphatase concentration (King Armstrong units/100 ml) in twenty children with a normal vitamin $A$ intake, before and $24 h$ after an oral dose of Io 000 i.u. vitamin $A$

\begin{tabular}{cc}
\multicolumn{2}{c}{ (Mean values and standard deviations) } \\
Before & After \\
$18 \cdot 6 \pm 4 \cdot 8$ & $15 \cdot 8 \pm 4 \cdot 9$ \\
$(13 \cdot 1-29 \cdot 7)$ & $(8 \cdot 6-24 \cdot 0)$
\end{tabular}

On completion of the balance studies, the diet was modified by the inclusion of green leafy vegetables. Each child was given $30 \mathrm{~g}$ of vegetables a day, which provided approximately 2500 i.u. vitamin $\mathrm{A}$, as carotene, and increased the total $\mathrm{Ca}$ intake to an average of $28 \mathrm{I} \mathrm{mg}$ a day. The children were on the modified diet for 2 months when further balance studies were undertaken.

Three-day $\mathrm{Ca}$ balances were repeated in twenty subjects; the results are shown in Table 2 . The mean absorption was now $\mathrm{r} 76 \cdot 2 \mathrm{mg}$ a day. The faecal excretion remained the same, $105.5 \mathrm{mg}$, but the urinary excretion was somewhat higher than previously, $34.3 \mathrm{mg} /$ day. The retention was, on an average, $\mathrm{I} 4 \mathrm{I} \mathrm{mg}$, or $54 \%$ of the intake.

The serum alkaline phosphatase was determined in subjects receiving the modified diet before and $24 \mathrm{~h}$ after an oral dose of to $000 \mathrm{i}$.u. vitamin A ('Table 5). No significant changes in the serum alkaline phosphatase were observed this time, when the children were on an adequate intake of carotene.

\section{DISCUSSION}

It is well documented that children under the age of 5 years are a vulnerable group, susceptible to all kinds of dietary deficiencies. However, on daily $\mathrm{Ca}$ intakes as low as $200 \mathrm{mg}$ the children maintained positive balances.

Animal studies have shown that the amount of $\mathrm{Ca}$ required to maintain balance is largely a reflection of the customary Ca intake. Kinsman, Sheldon, Jensen, Bernds, 
Outhouse \& Mitchell (1939) have shown that the maintenance level for children is very low and $\mathrm{Ca}$ is utilized efficiently when it is needed for the formation of new bone.

The results of the present study support the view that positive $\mathrm{Ca}$ balances in human beings may be achieved at well below the normally recommended levels of Ca intake (Basu, Basak \& Rai Sirkar, 1939; Nicholls \& Nimalasuria, r939; Owen, Irving \& Layall, I940).

Greenberg, Barry \& Mayer (I952) and Henry \& Kon (I953) are of the opinion that there may be an optimum intake of protein for the maximum utilization of $\mathrm{Ca}$. The children in the present study were given $2 \mathrm{~g}$ of vegetable protein per $\mathrm{kg}$ body-weight, which, according to the FAO/WHO standards (WHO, I965), is adequate for the preschool group. The diet also provided sufficient calories, and we attribute the favourable retention of $\mathrm{Ca}$ to the adequacy of the diet with regard to protein and calories.

From dietary surveys conducted in this area, it was found that rural preschool children consume $\mathrm{I} \cdot 6-\mathrm{I} \cdot 8 \mathrm{~g}$ protein per $\mathrm{kg}$ body-weight (Sundararaj et al. I $969 a, b$ ), a level also satisfactory by the FAO/WHO standards (WHO, 1965). However, the children of the rural areas had a low calorie intake $(70-75 \mathrm{kcal} / \mathrm{kg}$ body-weight $)$. The diet eaten by children in this part of India is therefore similar to the diet of the children under study, apart from the shortage of calories.

It remains to be investigated whether children with an inadequate calorie intake, with its influence on protein utilization, maintain positive balance on low intakes of $\mathrm{Ca}$.

Mitchell (I939) estimated that adults require ro mg of dietary Ca per $\mathrm{kg}$ bodyweight per day. However, Leitch \& Aitken (1959) have estimated that children need from 92 to $93 \mathrm{mg} \mathrm{Ca}$ a day for skeletal growth from the 2 nd year of life. They suggest that an additional intake of $50-60 \mathrm{mg}$ is needed for extraskeletal requirements. This would indicate that a preschool child needs about $150 \mathrm{mg}$ Ca daily and that the children in the present study need about I I $\mathrm{mg} \mathrm{Ca} / \mathrm{kg}$ body-weight, a figure similar to that suggested by Mitchell (1939) for the adult.

In the present study the children retained about $33 \%$ of their Ca intake and had an average daily retention of $79 \mathrm{mg}$, just over half the requirements as estimated by Leitch \& Aitken (1959). Though the children were on such a low-Ca diet for several months, growth was sustained. When green vegetables were included in the diet the intake of $\mathrm{Ca}$ increased to $28 \mathrm{I} \mathrm{mg} / \mathrm{child}$ and the retention of $54 \%$ resulted in a positive balance of $154 \mathrm{mg}$, on the average. The rate of growth on this increased intake, observed over 6 months, remained the same as on the lower $\mathrm{Ca}$ intake. It is not certain whether the increased $\mathrm{Ca}$ retentions observed after modification of the diet were due to the increased intake of $\mathrm{Ca}$ or to the vitamin $\mathrm{A}$ provided by the greens.

There are contradictory reports on the value of larger $\mathrm{Ca}$ intakes. Nicholls \& Nimalasuriya (1939) have shown that Ceylonese children with very low intakes utilized dietary Ca more efficiently than children studied in the United States.

According to reports by Macy (1942) an increase in the dietary Ca of preschool children results in higher retention. Children fed 339, 555, 707 and $904 \mathrm{mg} \mathrm{Ca}$ retained $62,103,125$ and $154 \mathrm{mg}$ a day respectively. However, the significance of the higher retention is not understood. 
The fat intake of the children in the present study was higher than that of the average south Indian child. No adverse effect on the absorption and retention of $\mathrm{Ca}$ was noted, as was also demonstrated by Nicolaysen, Eeg-Larsen \& Malm (1953), and Kane, Lovelace \& McCay (1949).

Serum levels of alkaline phosphatase were within the normal range, which indirectly confirms the adequacy of vitamin $\mathrm{D}$. In a tropical climate vitamin $\mathrm{D}$ deficiency is unlikely in rural children whose skin is exposed to the sun for several hours a day.

The effect of vitamin $A$ in lowering the level of alkaline phosphatase from a mean value of 16.4 units to 5.0 units/100 $\mathrm{ml}$ cannot be explained. This effect was observed on giving to $000 \mathrm{i}$.u. vitamin $A$ in oil orally to children who were on a diet very low in vitamin A. However, this effect was not observed when the dose was given to children with adequate vitamin $A$ intakes.

It has been generally believed that the ratio of $\mathrm{Ca}$ to $\mathrm{P}$ should be approximately $\mathrm{I}: \mathrm{I}$ and that high concentrations of $\mathrm{P}$ precipitate $\mathrm{Ca}$ as insoluble calcium phosphate, making it less available to the body. Malm (I953) has demonstrated that adults given excess $\mathrm{P}$ by mouth for $4^{-6}$ weeks maintained normal $\mathrm{Ca}$ balances. In our study the ratio of $\mathrm{Ca}$ to $\mathrm{P}$ was $\mathrm{I}: 3$. It appears that there was no interference with the $\mathrm{Ca}$ absorption judged by the amount of $\mathrm{Ca}$ retained. Beal (1968) is of the opinion that the ratio of $\mathrm{Ca}$ to $\mathrm{P}$ is a physiological need that changes with growth of various body components, and that the retention ratio of $\mathrm{Ca}$ to $\mathrm{P}$ is of greater importance than the dietary ratio. The results confirm this point of view and that of Widdowson, McCance, Harrison \& Sutton (1963), who have suggested that the concept of dietary ratios is outmoded. Studies carried out by Shenolikar ( 1966 ) have indicated that the chemical composition of bones of subjects subsisting on diets of poor nutritive value and low in $\mathrm{Ca}$ is not very different from that of the bones of adequately nourished normal subjects. However, investigations carried out in animals by El-Maraghi, Platt \& Stewart (1965) have shown that bones of animals fed on low-protein diets showed matrix osteoporosis and those of animals fed on diets low in $\mathrm{Ca}$ with adequate protein showed mineral osteoporosis.

Wasserman, Comar \& Nold (1956) and Lengemann \& Comar (1961) have indicated that the feeding of a single amino acid resulted in an increase in the absorption and intestinal transfer of $\mathrm{Ca}$. Stewart (1965) states that the amino acids lysine, arginine, leucine, tryptophan, valine and glycine brought about an improvement in the absorption of $\mathrm{Ca}$. When the retention and absorption of $\mathrm{Ca}$ by children on the lysinesupplemented wheat were compared with those of children on unsupplemented wheat, no differences were found between the two groups.

It can be concluded from the results presented that children of preschool age in tropical climates can maintain positive $\mathrm{Ca}$ balances on intakes of $200-300 \mathrm{mg}$ a day, provided their intakes of protein and calories are adequate. The Ca intakes of rural children in this part of India are around $200 \mathrm{mg}$. The protein intake of the children is approximately $\mathrm{I} \cdot 8 \mathrm{~g} / \mathrm{kg}$ body-weight, which is satisfactory, but the calorie intake is inadequate. Whether these children absorb and retain $\mathrm{Ca}$ as efficiently as the subjects of this study remains to be investigated. 
This study was supported by Agreement No. I 4302 PL 480 funds from the National Institutes of Health, United States Public Health Service. The authors wish to thank Mrs Molly Mammen and Mrs Jubilee Pratabkumar for technical assistance and Miss Sheila David for help in preparing the diets.

\section{REFERENCES}

Basu, K. P., Basak, M. N. \& Rai Sirkar, B. C. (1939). Indian 7. med. Res, 27, 47 I.

Beal, V. A. (г968). F. Am. diet. Ass. 53, 450.

Clark, E. P. \& Collip, J. B. (1925). F. biol. Chem. 63, 46r.

El-Maraghi, N. R. H., Platt, B. S. \& Stewart, R. J. C. (1965). Br. F. Nutr. I9, 491.

Fiske, C. H. \& Subbarow, Y. (1925). F. biol. Chem. 66, 375 .

Greenberg, R. M., Barry, M. G. \& Mayer, J. (1952). Fedn Proc. Fedn Am. Socs exp. Biol. Ir, 444.

Hegsted, D. (1959). Rev. Nutr. Res. 20, I3.

Henry, K. M. \& Kon, S. K. (1953). Br. F. Nutr. 7, 147.

Hooper, J. (1956). F. med. Lab. Technol. 13, 470.

Indian Council of Medical Research (1958). Rep. Nutr. Res. Lab. Hyderabad pp. 43-48.

Indian Council of Medical Research (1966). Sp. Rep. Ser. Indian Coun. med. Res. no. 42.

Kane, G. C., Lovelace, F. E. \& McCay, C. M. (r949).F. Geront. 4, I85.

King, E. J. \& Jagadesan, K. A. (1959). Ұ. clin. Path. 12, 85.

Kinsman, G., Sheldon, D., Jensen, E., Bernds, M., Outhouse, J. \& Mitchell, H. H. (1939). F. Nutr. I7, 429.

Leitch, I. \& Aitken, F. C. (1959). Nutr. Abstr. Rev. 29, 393.

Lengemann, F. W. \& Comar, C. L. (1961). Am. F. Physiol. 200, 1051.

Macy, I. C. (1942). Nutrition and Chemical Growth in Childhood. Vol. r. Evaluation p. 161. Springfield, Ill.: Charles C. Thomas.

Malm, O. J. (1953). Scand.F. clin. Lab. Invest. 5, 75 .

McCrudden, F. H. (1912). Э. biol. Chem. то, 187 .

Murthy, H. B. N., Swaminathan, M. \& Subrahmanyan, V. (1954). Br. F. Nutr. 8, 11.

Mitchell, H. H. (1939). The Dietary Requirement of Calcium and its Significance. Paris: Hermann et $\mathrm{C}^{\text {ie. }}$ (Actual. scient. ind. no. 77 I.)

National Research Council: Food and Nutrition Board (1968). Publs natn. Res. Coun., Wash. no. I694.

Nicholls, L. \& Nimalasuriya, A. (1939). F. Nutr. 18, 563 .

Nicolaysen, R., Eeg-Larsen, N. \& Malm, O. J. (1953). Physiol. Rev. 33, 424.

Owen, E. C., Irving, J. T. \& Layall, A. (1940). Acta med. scand. ro3, 235.

Shenolikar, I. S. (1966). Indian F. med. Res. 54, I I 3 I.

Stewart, R. J. C. (1965). Wld Rev. Nutr. Diet. 5, 276.

Sundararaj, R., Begum, A., Jesudian, G. \& Pereira, S. M. (I969a). Indian F. med. Res. 57, 249.

Sundararaj, R., Begum, A., Jesudian, G. \& Pereira, S. M. (1969b). Indian f. med. Res. 57, 375.

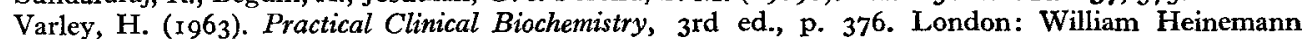
Medical Books Ltd.

Wasserman, R. H., Comar, C. L. \& Nold, M. N. (1956). F. Nutr. 59, 37 I.

Widdowson, E. M., McCance, R. A., Harrison, G. E. \& Sutton, A. (1963). Lancet ii, 1250.

WHO (1962). Tech. Rep. Ser. Wld Fllth Org. no. 230.

WHO (1965). Tech. Rep. Ser. Wld Hlth Org. no. 30 I. 